\title{
Optimalisasi Pemanfaatan Microsoft Power Point dalam Pembuatan Materi Ajar yang Kreatif Bagi Guru SMK Nurul Iman di Era New Normal
}

\author{
Guntoro Barovih¹, Febria Sri Handayani², Stevanius Lie ${ }^{3}$ \\ 1,3Jurusan S1 Informatika, STMIK Palcomtech, Palembang, Indonesia \\ ${ }_{2}^{2}$ Jurusan S1 Sistem Informasi, STMIK Palcomtech, Palembang, Indonesia \\ *e-mail: guntoro@palcomtech.ac.id ${ }^{1}$, febria_sri@palcomtech.ac.id ${ }^{2}$, stevenusnull21@ gmail.com ${ }^{3}$
}

\begin{abstract}
The Covid 19 pandemic has changed all human life habits, not only changing lifestyles but also changing teaching and learning activities. Teaching and learning activities are now changing from face-toface, now virtual face-to-face using the video converence application. One of the effects of online learning activities felt by students is boredom in learning. So there must be innovations made by teachers as educators in delivering subject matter. One way is to apply use of attractive, creative and innovative presentation slides. The method used in this activity is training to make interactive and interesting presentation slides. The purpose of this activity is to explore the potential of teachers in making creative and interesting learning media to convey so that students are more focused and not bored in participating in learning activities. The results of this activity were obtained by many teachers who were familiar with using presentation media tools both in the form of offline tools and online tools.
\end{abstract}

Keywords: COVID-19 pandemic, creativity, innovation, presentation

\begin{abstract}
Abstrak
Pandemic Covid 19 telah merubah seluruh kebiasaan hidup manusia tidak hanya mengubah pola hidup tetapi juga mengubah kegiatan belajar dan mengajar. Kegiatan belajar dan mengajar saat ini berubah yang sebelumnya tatap muka secara langsung, sekarang berubah menjadi tatap muka secara virtual menggunakan aplikasi video converence. Salah satu efek dari kegiatan belajar secara daring yang dirasakan oleh para peserta didik adalah kejenuhan dalam belajar. Maka harus ada inovasi yang dilakukan oleh para guru sebagai pendidik dalam menyampaikan materi pelajaran. Salah satunya adalah dengan menerapkan penggunaan slide presentasi yang menarik, kreatif dan inovatif. Metode yang dilakukan dalam kegiatan ini adalah pelatihan membuat slide presentasi yang interaktif dan menarik. Tujuan dari kegiatan ini adalah menggali potensi guru dalam membuat media pembelajaran yang kreatif dan menarik menggunakan Microsoft Power Point untuk disampaikan sehingga para peserta didik semakin focus dan tidak jenuh dalam mengikuti kegiatan belajar. Selain itu mengintegrasikannya dengan aplikasi pembelajaran dalam jaringan lainnya. Hasil dari kegiatan ini banyak didapatkan guru-guru yang paham dalam menggunakan tools media presentasi baik dalam bentuk offline tools maupun online tools.
\end{abstract}

Kata kunci: pandemic covid 19, kreatifitas, inovasi, presentasi

\section{PENDAHULUAN}

Dunia Pendidikan merupakan salah satu sektor kegiatan yang terdampak dari pesatnya penyebaran wabah corona virus disease 2019 (covid-19) dan hal ini menjadi tantangan tersendiri bagi Lembaga Pendidikan. Melalui surat edaran yang diterbitkan oleh Kementerian Pendidikan dan kebudayaan telah melarang pelaksanaan kegiatan Pendidikan secara konvensional (tatap muka) dan pemerintah memerintahkan untuk melakukan kegiatan Pendidikan secara daring agar kegiatan belajar dan mengajar bisa terus berlangsung (Sadikin and Hamidah 2020).

Pembelajaran daring mendapatkan tanggapan yang sangat baik khususnya pada fleksibilitas dalam pelaksanaannya dan juga bisa memicu kemandirian dalam belajar untuk bisa lebih aktif. Tetapi pembelajaran daring memiliki keterbatasan-keterbatasan tersendiri dimana pendidik tidak bisa memantau secara langsung para peserta didik pada saat kegiatan belajar berlangsung, serta sulitnya para peserta didik untuk memahami bahan ajar yang disampaikan secara online (Firman and Rahayu 2020). Selain itu kompetensi dan keterampilan guru dalam membawakan bahan ajar ke peserta didik juga perlu ditingkatkan dan tidak boleh semata-mata 
hanya memberikan tugas saja. Keterlibatan peran sekolah juga harus ada dengan cara mendorong para guru untuk terus belajar dan diperkaya khasanan keilmuannya, sehingga pembelajaran akan tercapai secara optimal (Wahyono, Husamah, and Budi 2020). Oleh karena itu, perlu adanya kreatifitas bagi guru dalam menekan keterbatasan dan kesulitan yang dihadapi oleh para peserta didik agar bahan ajar bisa tersampaikan dengan baik dan bisa di pahami oleh para peserta didik. Berbagai media perlu diterapkan dalam mendukung kegiatan pembelajaran dari seperti memanfaatkan teknologi informasi. Teknologi informasi sangat membantu dalam peroses pembelajaran daring khususnya pada kondisi pandemic covid-19 saat ini (Pakpahan and Fitriani 2020). Tidak hanya sebatas pemanfaatan teknologi saja. Agar bahan ajar bisa diserap baik oleh para peserta didik, maka peserta didik harus memaksimalkan kemampuan belajar dalam kondisi pandemic seperti saat ini (Herliandry et al. 2020).

Dengan maksud yang sama seperti penjabaran diatas, maka STMIK PalComTech Palembang bekerja sama dengan SMK Nurul Iman Palembang dalam sebuah kegiatan pengabdian masyarakat. Hal ini juga merupakan bentuk kepedulian dan sumbangsih dari para dosen STMIK PalComTech Palembang dalam upaya turut mendukung peningkatan kompetensi para guru dalam menciptakan media dan materi pembelajaran yang menarik dengan menggunakan Microsoft Power Point. Pemanfaatan Microsoft power point sudah sangat luas mulai dari pemanfaatan untuk belajar matematika khususnya pada siswa SMP kelas VIII, dimana mata pelajaran matematika merupakan mata pelajaran yang sangat sulit untuk dipahami dan butuh konsentrasi yang bagus. Untuk itu perlu dilakukan suatu strategi dimana mata pelajaran mudah dipahami dan menyenangkan sehingga mudah di serap oleh siswa, maka para guru menyajikan ini menggunakan power point dengan penyajian yang dinamis (Hikmah and Maskar 2020). Selain itu Microsoft power point juga bisa di integrasikan dengan aplikasi tambahan untuk membuat slide presentasi menjadi lebih menarik dengan mengubah slide presentasi menjadi flash atau animasi, sehingga slide presentasi menjadi lebih menarik dan menyenangkan untuk dilihat dan bisa membuat focus siswa dalam belajar serta bisa meningkatkan motifasi siswa dalam belajar (Khotimah 2019). Selain belajar matematika dan pelajaran umum lainnya, micrososft power point juga digunakan untuk mata pelajaran bahasa arab yang diintegrasikan melalui aplikasi android untuk memudahkan dan membantu siswa dalam belajar Bahasa arab secara dinamis dan mandiri (Nurhidayati et al. 2019).

Latar belakang dilakukannya kegiatan pelatihan optimalisasi MS.Power Point untuk pembuatan media pembelajaran interaktif di SMK Nurul Iman Palembang ini utamanya didasarkan pada kondisi pandemic Covid-19 yang melanda Indonesia, khususnya satuan pendidikan di kota Palembang. Pandemic Covid-19 dan peraturan pemerintah mengharuskan sebagian besar proses kegiatan belajar mengajar (KBM) disekolah harus dapat dilakukan secara daring. Hal ini bertujuan untuk mengurangi intensitas temu fisik antar warga sekolah (guru, siswa, dan staf tata usaha). Selain itu juga merujuk pada keterbatasan para guru dan siswa dalam menjalani sekolah dan pembelajaran jarak jauh dalam jaringan (PJJ/daring) dan keterbatasan peralatan penunjang KBM yang tersedia. Baik siswa maupun guru memiliki keterampilan dan pemahaman yang cukup untuk bidang teknologi. Tidak semua guru, terutama guru senior yang mampu mengoperasikan aplikasi komputer dan internet dalam pembelajaran daring, begitu juga dengan para siswa. Keterbatasan sarana-prasarana penunjang KBM seperti laptop, smartphone, koneksi internet, dan aksesoris lainnya yang dimiliki oleh masing-masing siswa, guru, dan sekolah juga turut menghambat proses pembelajaran PJJ/daring. Tak jarang pihak sekolah terpaksa mengizinkan guru dan siswa untuk temu fisik untuk menuntaskan permasalahan dalam KBM yang tidak bisa diselesaikan secara daring. Walaupun terkesan "melanggar" peraturan dan edaran Dinas Pendidikan dan Kebudayaan setempat, namun hal ini terpaksa dilakukan demi meningkatkan kualitas pembelajaran dan prestasi para siswa. Oleh karena itu, STMIK PalComTech sebagai salah satu perguruan tinggi di kota Palembang yang bergerak dibidang teknologi dan komputer merasa turut terpanggil untuk membantu memberikan solusi bagi pelaksanaan KBM dan peningkatan kualitas pembelajaran guru dan siswa disekolah. Hal ini diwujudkan melalui implementasi salah satu Tri Dharma Dosen yaitu kegiatan pengabdian kepada masyarakat. 


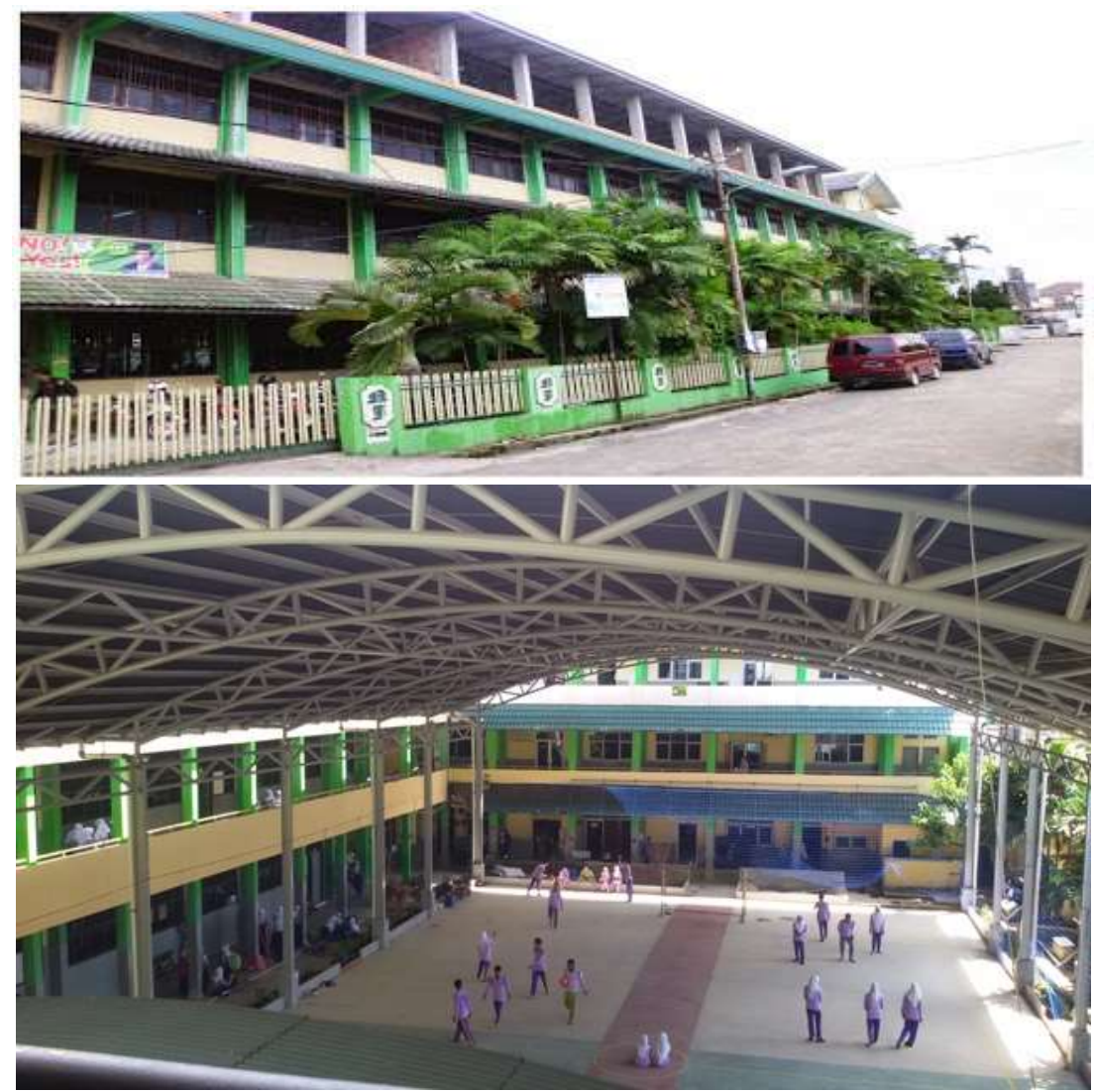

Gambar 1. Suasana SMK Nurul Iman Palembang

Kegiatan pengabdian kepada masyarakat rutin dilakukan oleh para dosen STMIK PalComTech Palembang. Kegiatan ini merupakan salah satu bentuk implementasi Tri Dharma Dosen Perguruan Tinggi. Dimana setiap dosen diwajibkan untuk melakukan kegiatan pendidikan dan pengajaran, penelitian, serta pengabdian kepada masyarakat, disamping kegiatan penunjang profesi dosen lainnya. Mitra yang jadi target kegiatan pengabdian kepada masyarakat yang dilakukan oleh para dosen STMIK PalComTech Palembang dikhususkan pada guru dan siswa SMP/SMA/SMK/sederajat yang ada di kota Palembang. Untuk kegiatan kali ini akan diselenggarakan dan bekerja sama dengan Sekolah Menengah Kejuruan (SMK) Nurul Iman Palembang. SMK Nurul Iman Palembang merupakan salah satu sekolah menengah kejuruan swasta yang bernaung dibawah binaan Yayasan Nurul Iman Palembang. SMK Nurul Iman berlokasi yang sama dengan SMA dan SMP Nurul Iman Palembang. Sekolah ini berdiri di atas lahan 2.660 M2. Lokasi dari SMK Nurul Iman berada di jalan Mayor Salim Batubara No. 358 Sekip Jaya (Kebon Semai), Palembang.

Merujuk pada hasil observasi dan wawancara dengan Kepala Sekolah SMK Nurul Iman Palembang, dan juga melihat kebutuhan sekolah pada saat itu, maka tema pelatihan yang ditetapkan untuk kegiatan pengabdian masyarakat kali ini adalah Pelatihan Optimalisasi MS.Power Point untuk pembuatan media pembelajaran interaktif bagi guru SMK Nurul Iman Palembang.

\section{METODE}

Pelaksanaan kegiatan pengabdian masyarakat ini dilakukan di SMK Nurul Iman Palembang yang berlokasi di jalan Mayor Salim Batubara No.358, Sekip Jaya, Kecamatan Kemuning, Palembang. Kegiatan berlangsung mulai dari tanggal 6 Februari 2021sampai tanggal 8 Februari 2021. Adapun jumlah guru yang terlibat sebanyak 20 peserta. Kegiatan ini ditunjang 
dengan fasilitas ruang pelatihan, laptop, proyektor, dan peralatan lainnya baik yang disediakan oleh pihak SMK Nurul Iman ataupun dari STMIK PalComTech.

Keunikan yang diusung dalam kegiatan pengabdian kepada masyarakat yang dilakukan oleh para dosen STMIK PalComTech Palembang adalah fokus pada peningkatan keterampilan aplikasi perkantoran dan komputer bagi guru dan siswa pada satuan pendidikan terutama SMP/SMA/SMK/Sederajat di kota Palembang

Kegiatan pengabdian kepada masyarakat yang dilakukan dalam bentuk pendampingan dan pelatihan ini bersifat kegiatan yang memiliki problem solving bagi kegiatan KBM disekolah baik secara daring maupun luring. Pada saat pelatihan, peserta juga dibekali dengan modul latihan yang dibuat langsung oleh pemateri kegiatan, disertai juga dengan kontak personal untuk keperluan diskusi setelah atau diluar jadwal pelaksanaan kegiatan. Selain pemateri, biasanya tim pelaksana kegiatan terdiri dari minimal satu dosen dan dua mahasiswa pendamping dengan masing-masing bidang keahlian yang sesuai dengan tema kegiatan dan dari setiap prodi yang melaksanakan kegiatan tersebut. Pelatihan dilakukan dengan berbagi tips dan trik dalam membuat materi pembelajaran yang menarik menggunakan power point dan disertai contoh kasus sesuai kebutuhan pembelajaran yang dihadapi saat ini diantaranya :

a. Kebutuhan dalam meningkatkan kompetensi khususnya dalam penyampaian materi dimana proses kegiatan belajar menggunakan mode Pembelajaran Jarak Jauh (PJJ).

b. Kebutuhan dalam meningkatkan kreatifitas guru dalam membuat slide presentasi materi mata pelajar an sehingga bisa memicu siswa untuk tertarik dan fokus belajar dan memperhatikan materi pelajaran pada saat PJJ berlangsung.

c. Kebutuhan bagi guru untuk mengeksplorasi kemampuan dan pemahaman tools apa saja yang bisa digunakan pada Microsoft power point dalam membuat slide materi yang baik dan menarik, sehingga siswa bisa fokus dalam belajar.

d. Kebutuhan bagi guru untuk bisa menguasai penggunakan Microsoft power point dengan sangat baik.

Tahapan aktivitas yang dilakukan dalam kegiatan pengabdian kepada masyarakat ini, diantaranya:

a. Promosi dan sosialisasi kegiatan pkm pada sekolah mitra dan Pengurusan administrasi : Tim melakukan observasi, menentukan jumlah peserta pelatihan, dan membuat kesepakatan kerjasama dengan SMK Nurul Iman Palembang.

b. Pelatihan dan pendampingan : Kegiatan dilaksanakan di ruang guru SMK Nurul Iman Palembang, yang dihadiri \pm 20 orang guru mata pelajaran.

c. Diskusi materi : Penyampaian materi pelatihan disertai demonstrasi oleh tutor mengenai fitur unik yang dimiliki Microsoft power point yang bisa digunakan untuk membuat beragam materi belajar yang menarik dan mempraktekkan bersama-sama contoh kasus yang diberikan tutor dalam membuat materi pembelajaran yang menarik.

d. Evaluasi kegiatan : Kegiatan diskusi dan berbagi pengalaman mengajar dalam mode PJJ di era new normal ini. Pretest dan posttest sebelum dan sesudah kegiatan.

e. Tindak lanjut hasil evaluasi

Guna mensukseskan kegiatan pengabdian yang dilaksanakan STMIK PalComTech, maka SMK Nurul Iman Palembang sebagai mitra berperan aktif melalui :

a. Mengundang para guru untuk bisa berperan aktif atau berpartisipasi dalam pelatihan yang dilakukan oleh tim pelaksana pengabdian masyarakat.

b. Menyediakan ruang/tempat untuk tim pelaksana dalam malaksanakan pengabdian.

c. Menyediakan akses internet bagi guru dan tim dalam mendukung kelancaran kegiatan pengabdian masyarakat yang dilaksanakan.

Untuk pembiayaan kegiatan didasarkan pada rencana anggaran biaya (RAB) yang sebelumnya telah disusun oleh ketua tim pelaksana kegiatan, dan telah disetujui oleh Ketua STMIK PalComTech Palembang. Selain itu, untuk prasarana lainnya tak jarang pihak sekolah pun 
turut andil dalam mendukung pelaksanaan kegiatan ini, diantaranya memberikan support berupa ruang kegiatan (jika kegiatannya dilakukan secara luring), koneksi internet, laptop tambahan, dan prasarana lainnya. Akan tetapi hal tersebut tidak terjadi disetiap sekolah mitra kegiatan, dan jika support tersebut tidak ada maka sepenuhnya diupayakan oleh para tim pelaksana demi kelancaran kegiatan.

Beberapa poin penting yang dapat dijadikan pertimbangan oleh Ketua STMIK PalComTech dan Kepala Sekolah mitra untuk menyetujui pelaksanaan kegiatan pengabdian kepada masyarakat yang dilakukan oleh para dosen, diantaranya :

1. Spesifikasi bidang keahlian para dosen STMIK PalComTech yang telah disesuaikan dengan tema kegiatan yang akan dilaksanakan pada sekolah mitra.

2. STMIK PalComTech Palembang berkesempatan untuk menambah mitra untuk menjalin kerja sama kegiatan penelitian dan pengabdian bagi para dosennya.

3. Promosi dan pengenalan kampus mengenai visi dan misi perguruan tinggi, kegiatan akademik dosen dan mahasiswa, peluang kerja sama perusahaan, peluang kerja bagi para lulusan, dan hal positif lainnya yang dapat dibagikan pada mitra untuk diketahui bersama dan disebarluaskan.

Kunci utama bagi terlaksananya kegiatan ini sebenarnya bersumber dari kemampuan dan bidang keahlian yang dimiliki oleh masing-masing dosen STMIK PalComTech Palembang untuk turut berkontribusi bagi kemajuan dan peningkatan kualitas pendidikan dikota Palembang, khususnya pembelajaran di sekolah. STMIK PalComTech memiliki dua program studi yaitu Informatika dan Sistem Informasi. Kedua program studi ini bergerak dibidang teknologi komputer (jaringan dan perangkat lunak). Adapun bidang keahlian yang dimiliki oleh para dosen dari kedua program studi ini, diantaranya :

1) Analis sistem,

2) Pemrograman,

3) Rekayasa perangkat lunak,

4) Pengolahan data dan informasi,

5) Arsitektur komputer,

6) Keamanan dan jaringan komputer,

7) Matematika dan statistika, serta

8) Bisnis dan manajemen.

Selain bertumpu pada bidang keahlian dan keterampilan setiap dosen, perangkat penunjang lainnya yang juga dibutuhkan untuk pelaksanaan kegiatan ini adalah laptop, aplikasi pendukung (MS.Office), koneksi internet, LCD proyektor, dan banner kegiatan. Semua perangkat penunjang ini sudah dimiliki dan pasti dibawa oleh tim pelaksana pada saat pelaksanaan kegiatan pelatihan tersebut.

Informasi mengenai pelaksanaan kegiatan pelatihan sebagai bentuk implementasi pengabdian kepada masyarakat ini didapatkan oleh para dosen melalui tim marketing STMIK PalComTech Palembang yang juga melaksanakan Road Show ke setiap satuan pendidikan di kota Palembang dan sekitarnya. Selain itu, bagi para dosen yang juga memiliki koneksi dan komunikasi secara personal dengan pihak sekolah juga bisa berbagi informasi mengenai kegiatan ini. Kemungkinan distribusi informasi lainnya juga tidak menutup kemungkinan berasal dari pihak sekolahnya sendiri yang menghubungi STMIK PalComTech Palembang untuk dapat bekerja sama dalam kegiatan peningkatan keterampilan komputer bagi para guru disekolah tersebut. Dengan komunikasi yang baik dan kemitraan yang berkelanjutan, tak menutup kemungkinan kegiatan pelatihan yang sifatnya insidental dapat dijadwalkan secara terstruktur dan berkelanjutan kedepannya. 


\begin{tabular}{|c|c|c|c|c|}
\hline 1. Permasalahan & 4. Aktivitas Utama & $\begin{array}{c}\text { 1. Keunikan } \\
\text { (Volue Proposition) }\end{array}$ & 5. Keunegulan & $\begin{array}{l}\text { 2. Target Pelangsan / } \\
\text { Segmentasi Pasar. }\end{array}$ \\
\hline \multirow{3}{*}{$\begin{array}{l}\text { 1) Pandemi covid-19 dan } \\
\text { peraturan pemerintah yang } \\
\text { mengharuskan sebagian besar } \\
\text { proses KBM dapat dilakukan } \\
\text { secara daring. } \\
\text { 2) Keterbatasan para guru dan } \\
\text { siswa dalam pembelajaran } \\
\text { jarak jauh. } \\
\text { 3) Keterampilan guru dalam } \\
\text { menggunakan MS. Pawer Point } \\
\text { dalam pembuatan media } \\
\text { pembelajaran interaktif. } \\
\text { 3) Trend dan fenomena } \\
\text { penyelenggaraan sekolah } \\
\text { daring dari tiap sekolah. }\end{array}$} & $\begin{array}{l}\text { 1) Promost dan Sosialisast } \\
\text { Kegiatan PKM } \\
\text { 2) Pengurusan administrasi } \\
\text { 3) Pelatihan dan } \\
\text { pendampingan } \\
\text { 4) Diskusi Materi } \\
\text { 5) Evaluasi Kegiatan } \\
\text { 6) Tindak lanjut hasil evaluasi }\end{array}$ & \multirow{3}{*}{$\begin{array}{l}\text { Fokus pada peningkatan } \\
\text { keterampilan aplikasi } \\
\text { perkantoran dan komputer bagi } \\
\text { guru dan siswa padia satuan } \\
\text { pendidikan terutama } \\
\text { SMP/SMA/SMK/Sederajat dii } \\
\text { Kota Palembang. }\end{array}$} & $\begin{array}{l}\text { 1) Kegiatan yg Problem solving. } \\
\text { 2) Modul latihan. }\end{array}$ & \multirow[t]{3}{*}{$\begin{array}{l}\text { Guru dan siswa } \\
\text { SMP/SMA/SMK/Sederajat } \\
\text { di Kota Palembang }\end{array}$} \\
\hline & $\begin{array}{l}\text { 8. Sumber Daya } \\
\text { (Manusla/Mesin) }\end{array}$ & & $\begin{array}{l}\text { 9. Distribusi } \\
\text { (Channels) }\end{array}$ & \\
\hline & $\begin{array}{l}\text { 1) Dosen STMIK PaiComTech } \\
\text { 2) Laptop, internet, MS.Office }\end{array}$ & & $\begin{array}{l}\text { 1) Tim marketting STMIK } \\
\text { PaicomTech } \\
\text { 2) Kepala Sekolah ybs }\end{array}$ & \\
\hline & $\begin{array}{l}\text { 6. Struktur Bisya } \\
\text { (Cost Structure) }\end{array}$ & & $\begin{array}{l}\text { 7. Nilai Jual } \\
\text { (Revenue Streoms) }\end{array}$ & \\
\hline \multicolumn{2}{|c|}{ RAB Kegiatan PKM Dosen STMIK. PaiComTech } & \multicolumn{3}{|c|}{$\begin{array}{l}\text { 1) Spesifikasi bidang keahlian para dosen STMIK PalComTech } \\
\text { 2) Menambah mitra untuk kerja sama kegiatan penelitian dan pongabdian } \\
\text { 3) Promosi Kampus }\end{array}$} \\
\hline
\end{tabular}

Gambar 2. Business plan Pengabdian kepada mastarakat STMIK Palcomtech

\section{HASIL DAN PEMBAHASAN}

Tim pelaksana pengabdian STMIK Palcomtech melaksanakan kegiatan pengabdian merupakan bentuk dukungan Perguruan tinggi dalam upaya meningkatkan kopetensi para guru dalam khususnya pada system belajar jarak jauh seperti saat ini di tengah pandemi covid 19. Karena itu, tim pelaksana pengabdian STMIK Palcomtech focus mencari solusi untuk memecahkan permasalahan yang di hadapi oleh mitra dalam kegiatan belajar di tengah pandemic covid 19 seperti saat ini. Hasil kegiatan yang dilakukan oleh tim pelaksana kegiatan pengabdian kepada mitra yaitu pertama, sebelum tim pelaksana kegiatan pengabdian melakukan kegiatan pelatihan. Tim melakukan penyebaran kuesioner pretest untuk melihat sebatas mana pengetahuan mitra tentang pemanfaatan Microsoft Office Power Point. Dalam hal ini adalah guruguru SMK Nurul Iman Palembang, sehingga materi apa saja yang sudah dan belum dikuasai atau dipahami dan dimaksimalkan pemanfaatannya dari fitur-fitur Microsoft Office Power Point yang digunakan.

Pretest digunakan untuk mengetahui sejauh mana materi atau bahan pelajaran yang akan diajarkan telah dapat dikuasai (Effendy 2016). Adapun yang ditanyakan dalam angket pretest tersebut diantaranya mengenai pengalaman para guru dalam penggunaan perangkat teknologi dalam kegiatan belajar mengajar, terutama Microsoft Power Point. Berdasarkan hasil pretest, sebagian besar peserta pelatihan sudah pernah menggunakan media berbasis teknologi dalam penyampaian materi pembelajaran. Selain menggunakan MS.Power Point sebagai media pembelajaran, para peserta pelatihan juga ada yang sudah pernah mengintegrasikan MS.Power Point bersama aplikasi lainnya seperti zoom, wag, google classroom, youtube, email, telegram dan berbagai jejaring sosial lainnya. Adapun beberapa media pembelajaran yang pernah dihasilkan oleh para peserta diantaranya slide presentasi materi belajar, power point show, video belajar. Mengenai fasilitas penunjang pembelajaran berbasis teknologi guna kelancaran proses pembelajaran jarak jauh, dalam hal ini pihak SMK Nurul Iman Palembang sangat menaruh perhatian khusus. Pihak sekolah memfasilitasi para guru dengan menyediakan PC/laptop, infokus/LCD proyektor, dan internet. Namun ternyata diketahui bahwa terdapat $41 \%$ guru yang belum mengetahui secara maksimal fitur-fitur pada Microsoft Office Power Point dan trik-trik dalam mebuat slide yang menarik agar para audience tidak merasa bosan dalam mendengarkan pemaparan materi. Angket pretest digunakan sebagai alat bantu untuk mengetahui seberapa besar tingkat pemahaman, pengetahuan dan penguasaan akan perangkat dalam hal ini adalah 
Microsoft power point (Fitriani and Setiawan 2018). Tabel 1 menunjukkan daftar pertanyaan yang diajukan pada saat pretest, sedangkan gambar 3 menunjukkan grafik jawaban responden.

Tabel 1. Daftar Pertanyaan Pretest Optimalisasi MS. Power Point

\begin{tabular}{|c|c|}
\hline Kode & Pernyataan \\
\hline P1 & $\begin{array}{l}\text { Peserta sudah menggunakan menggunakan media berbasis teknologi } \\
\text { dalam penyampaian materi pembelajaran, }\end{array}$ \\
\hline $\mathrm{P} 2$ & $\begin{array}{l}\text { Peserta sudah mahir dalam menggunakan media berbasis teknologi } \\
\text { dalam penyampaian materi pembelajaran. }\end{array}$ \\
\hline P3 & $\begin{array}{l}\text { Sekolah memberikan fasilitas penunjang pembelajaran berbasis } \\
\text { teknologi guna kelancaran proses pembelajaran, diantaranya (boleh pilih } \\
\text { salah satu atau beberapa): } \\
\text { o PC / Laptop } \\
\text { o Smartphone } \\
\text { o Infokus } \\
\text { o Internet } \\
\text { o Lainnya : ................................ }\end{array}$ \\
\hline P4 & $\begin{array}{l}\text { Peserta pernah menggunakan Microsoft Power Point untuk membuat } \\
\text { media pembelajaran. }\end{array}$ \\
\hline P5 & $\begin{array}{l}\text { Peserta pernah mengintegrasikan Microsoft Power Point bersama } \\
\text { aplikasi lainnya untuk menghasilkan media pembelajaran. } \\
\text { Aplikasinya apa saja? }\end{array}$ \\
\hline P6 & $\begin{array}{l}\text { Peserta pernah menghasilkan media pembelajaran, } \\
\text { diantaranya (boleh pilih salah satu atau beberapa) : } \\
\text { o Slide presentasi materi belajar. } \\
\text { o Power Point Show } \\
\text { o Video (mp4) } \\
\text { o Game Power Point }\end{array}$ \\
\hline P7 & $\begin{array}{l}\text { Peserta pernah mendistribusikan media pembelajaran yang dibuat } \\
\text { menggunakan power point secara online? } \\
\text { Medianya : } \\
\text { o Instagram } \\
\text { o Facebook } \\
\text { o WhatsApp } \\
\text { o Telegram } \\
\text { o E-Mail } \\
\text { o Google Drive } \\
\text { o Lainnya } . . . . . . \ldots \ldots \ldots \ldots \ldots \ldots \ldots \ldots\end{array}$ \\
\hline
\end{tabular}

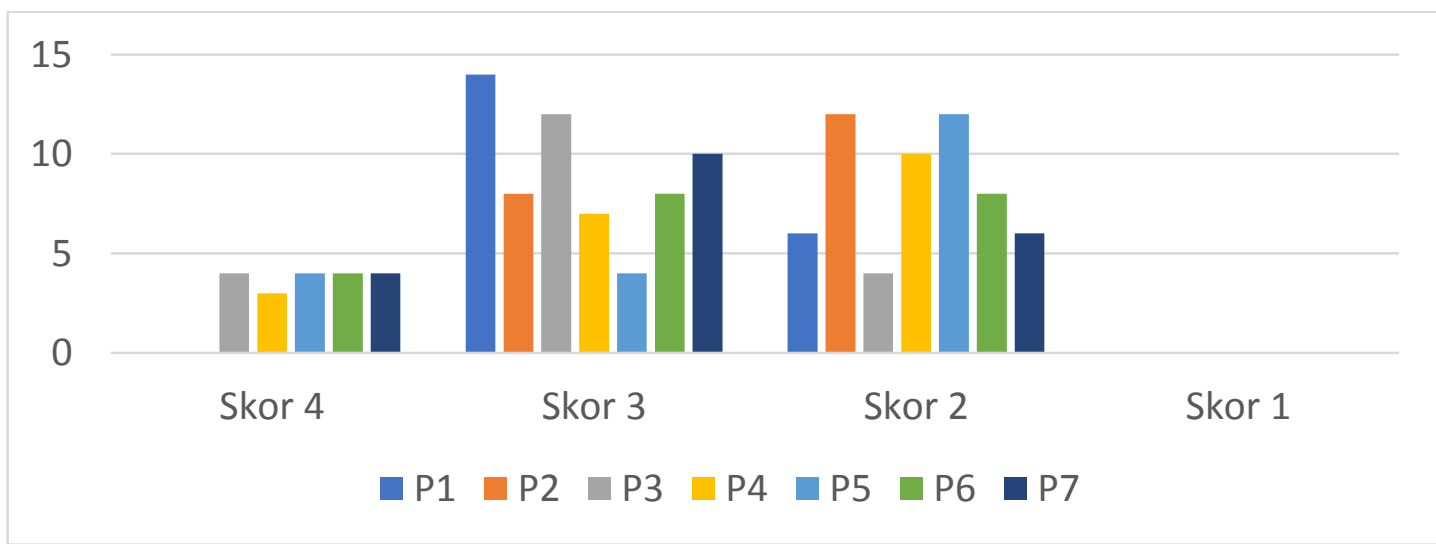

Gambar 3. Grafik Hasil Pretest Optimalisasi MS. Power Point 


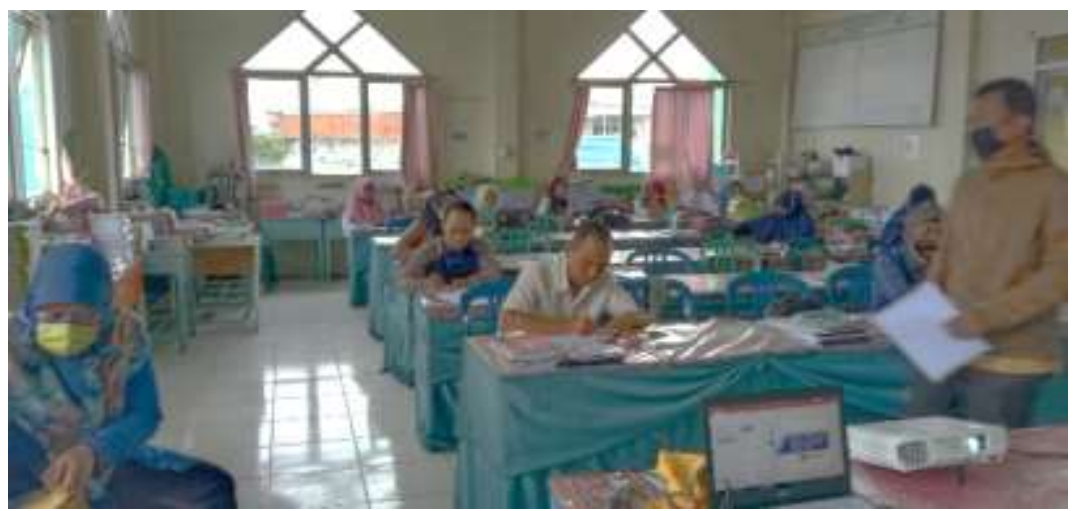

Gambar 4. Pengisian Pretest Sebelum Melakukan Pelatihan

Kedua, tim pelaksana pengabdian melakukan pelatihan sesuai dengan kebutuhan mitra sesuai dengan hasil pretest yang telah dilakukan sebelumnya. Dalam kegiatan ini tim pelaksana pengabdian menitik beratkan pada cara memanfaatkan secara maksimal fitur Microsoft office yang telah disediakan dan memanfaatkan aplikasi pendukung agar slide presentasi yang dihasilkan menjadi lebih menarik untuk disajikan dan siswa dalam belajar menjadi lebih fokus dalam memperhatikan materi yang disampaikan. Adapun materi pelatihan yang disajikan meliputi membuat slide presentasi dengan metode master slide dimana sub materi yang akan disampaikan ke audience semuanya terkolektif atau terkontrol di master slide yang memberikan kemudahan dalam navigasi slide. Selain materi pemanfaatan metode master slide tim pelaksana pengabdian juga memberikan wawasan dalam penggunaan aplikasi utility yang bisa digunakan dalam membuat slide menjadi dinamis dengan menggunakan bantuan aplikasi video editing. Selain menggunakan aplikasi editing juga diberikan pelatihana bagaimana menggunakan template dan animasi slide yang bisa membuat slide presentasi yang kita buat menjadi lebih menarik dan dinamis dengan menggunakan template dan animasi yang bebas di download dari internet atau bisa di buat sendiri.

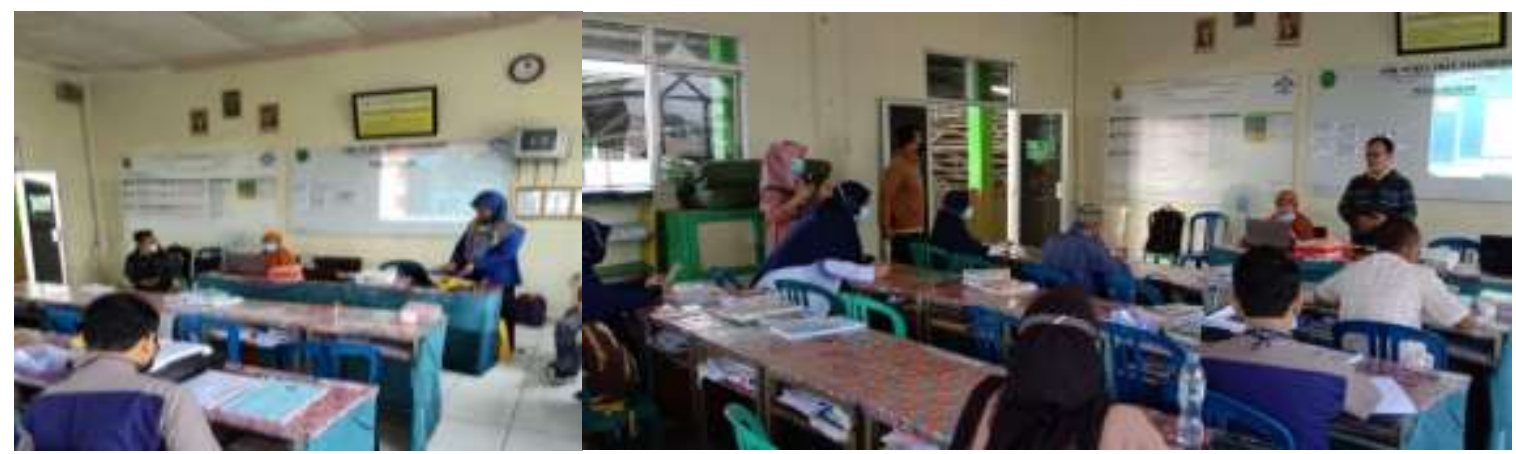

Gambar 5. Pemaparan Materi Pelatihan Pemanfaatan Microsoft Office

Ketiga, setelah melakukan pelatihan, maka tim pelaksana pengabdian melakukan kegiatan posttest. Posttest merupakan bentuk evaluasi akhir dari materi yang telah diberikan di hari itu dengan tujuan untuk melihat apakah peserta memahami dan mengerti dari materi yang sudah diajarkan (Istiani and Retnoningsih 2015; Pratiwi, Ardianti, and Kanzunnudin 2018; Sari, Lestari, and Awal 2018). Kegiatan posttest ini tim pelaksana lakukan guna melihat dan mengukur tingkat pemahaman para peserta dalam menggunakan dan memaksimalkan penggunaan perangkat lunak slide editor. Berdasarkan hasil posttest yang dilakukan, untuk pencapaian hasil kegiatan ini sebanyak $84 \%$ guru menyatakan sudah mulai memahami dan menguasai materi yang diajarkan. penguasaan materi yang dalam hal ini adalah Microsoft Office Power Point untuk membuat slide yang dinamis dan menarik sehingga pada saat para guru melakukan kegiatan pebelajaran kepada siswa, siswa tidak merasa jenuh dan metode pembelajaran yang dibawakan oleh guru terkesan monoton dan tidak mnarik. Dari hasil posttest ini juga dapat disimpulkan bahwa secara keseluruhan para peserta menyatakan puas dengan kegiatan pengabdian masyarakat yang dilakukan oleh dosen STMIK PalComTech Palembang. Standar kepuasan ini dilihat dari materi 
pelatihan yang diberikan dinilai cukup sesuai dengan kebutuhan peserta, disampaikan dengan jelas dan mudah dipahami, durasi pelatihan dirasa cukup, serta cara pemateri dalam menyampaikan materi yang baik dan memberi solusi. Para peserta berharap kedepannya kegiatan sejenis ini dapat dilakukan secara berkelanjutan. Tabel 2 menunjukkan daftar pertanyaan yang diajukan pada saat pretest, sedangkan gambar 6 menunjukkan grafik jawaban responden.

Tabel 2. Daftar Pertanyaan Posttest Optimalisasi MS. Power Point

\begin{tabular}{cl}
\hline Kode & \multicolumn{1}{c}{ Pernyataan } \\
\hline P1 & Kegiatan pelatihan yang dilaksanakan sesuai harapan peserta. \\
P2 & Materi pelatihan sesuai dengan kebutuhan peserta. \\
P3 & Materi yang disampaikan jelas dan mudah dipahami. \\
P4 & Durasi pelatihan dirasa cukup. \\
P5 & Cara pemateri menyajikan materi pelatihan tergolong menarik. \\
P6 & Anggota pendamping pelatihan memberikan pelayanan yang baik. \\
P7 & Setiap keluhan/pertanyaan/permasalahan yang diajukan peserta selama pelatihan \\
P8 & Peserta mendapatkan manfaat langsung dari kegiatan pelatihan ini. \\
P9 & Kegiatan pelatihan ini berhasil menambah pengetahuan peserta. \\
P10 & Sebaiknya kegiatan pelatihan dilakukan secara berkelanjutan. \\
& Peserta berminat untuk mengikuti kegiatan pelatihan lainnya selama sesuai kebutuhan \\
P11 & peserta. \\
P12 & Secara umum, peserta puas terhadap kegiatan pelatihan ini. \\
\hline
\end{tabular}

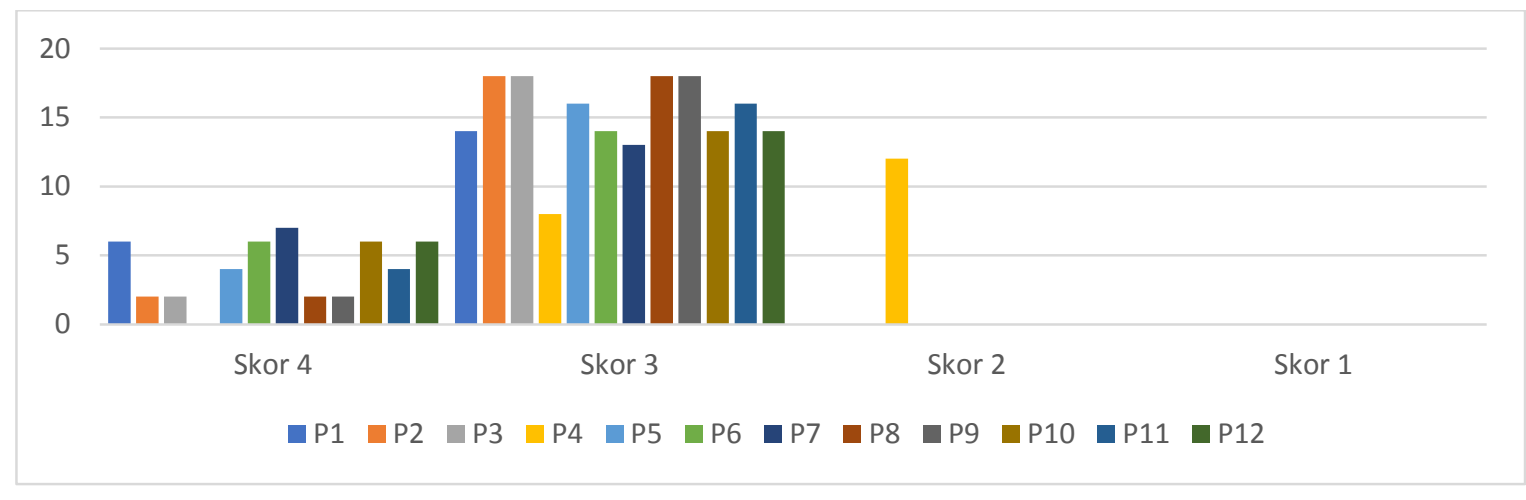

Gambar 6. Grafik Hasil Posttest Optimalisasi MS. Power Point

Dengan adanya posttest, para stackholder bisa melihat peningkatan kemampuan dari para guru disisi hardskill khususnya kemampuan penguasaan alat bantu pembelajaran bebrbasis TIK seperti Microsoft office. Juga bisa melihat peningkatan kopetensi guru dan kreatifitas guru dalam membuat suasana belajar menjadi menarik dan tidak membosankan bisa terpenuhi.

\section{KESIMPULAN}

Berdasarkan kegiatan pengabdian yang telah dilakukan. Metode pelatihan merupakan hal yang sangat baik untuk diterapkan khususnya pada kasus pengguasaan pengetahuan tentang teknologi seperti penguasaan perangkat lunak Microsoft office sehingga bisa di rasakan langsung oleh para peserta. Kegiatan pretest dan posttest merupakan hal yang penting untuk dilakukan khususnya bagi para tim pelaksana pengabdian dalam hal ini bisa disebut sebagai pelatih untuk melihat kemampuan awal dan akhir peserta sesudah mengikuti pelatihan apakah terjadi 
peningkatan atau tidak. Sehingga bis terlihat peningkatan kopetensi guru khususnya pada penguasaan teknologi yang digunakan dalam penyampaian materi. selain itu peningkatan kreatifitas guru juga bisa dilihat dari hasil pelatihan dalam bentuk produk-produk materi yang disampaikan yang akan digunakan dalam kegiatan pembelajaran. Serta wawasan guru dalam pemanfaatan teknologi menjadi lebih luas khususnya untuk menunjang kegiatan pembelajaran pada masa pandemi seperti saat ini.

\section{UCAPAN TERIMA KASIH}

Penulis mengucapkan terima kasih kepada STMIK Palcomtech yang telah memberikan dukungan penuh dalam bentuk materil dan non materil dan terima kasih kepada para mitra dalam hal ini SMK Nurul Iman yang telah memfasilitasi tim pelaksana pengabdian dalam bentuk ruang dan fasilitas lainnya.

\section{DAFTAR PUSTAKA}

Effendy, Ilham. 2016. "Pengaruh Pemberian Pre-Test Dan Post-Test Terhadap Hasil Belajar Mata Diklat HDW.DEV.100.2.a Pada Siswa SMK Negeri 2 Lubuk Basung." Jurnal Ilmiah Pendidikan $1(2): 81-88$.

Firman, Firman, and Sari Rahayu. 2020. "Pembelajaran Online Di Tengah Pandemi Covid-19." Indonesian Journal of Educational Science (IJES) 2(2):81-89.

Fitriani, Nur Intan, and Beni Setiawan. 2018. "Efektivitas Modul Ipa Berbasis Etnosains Terhadap Peningkatan Keterampilan Berpikir Kritis Siswa." Jurnal Penelitian Pendidikan IPA 2(2):71.

Herliandry, Luh Devi, Nurhasanah Nurhasanah, Maria Enjelina Suban, and Heru Kuswanto. 2020. "Pembelajaran Pada Masa Pandemi Covid-19." JTP - Jurnal Teknologi Pendidikan 22(1):65-70.

Hikmah, Sofia Nurul, and Sugama Maskar. 2020. "Pemanfaatan Aplikasi Microsoft Powerpoint Pada Siswa Smp Kelas VIII Dalam Pembelajaran Koordinat Kartesius." Jurnal Ilmiah Matematika Realistik 1(1):15-19.

Istiani, Rina Munawar, and Amin Retnoningsih. 2015. "Pemanfaatan Lingkungan Sekolah Sebagai Sumber Belajar Menggunakan Metode Post To Post Pada Materi Klasifikasi Makhluk Hidup." Journal of Biology Education 4(1):70-80.

Khotimah, Khusnul. 2019. "Pemanfaatanpowerpointterintegrasi Dengan I-Spring Presenter sebagai Media Pembelajaran ICT." Jurnal Eksponen 9(1):79-85.

Nurhidayati, Nurhidayati, Imam Asrori, Mohammad Ahsanuddin, and M. Wahib Dariyadi. 2019. "Pembuatan Media Pembelajaran Berbasis Powerpoint Dan Pemanfaatan Aplikasi Android Untuk Guru Bahasa Arab." Jurnal KARINOV 2(3):181.

Pakpahan, Roida, and Yuni Fitriani. 2020. "Analisa Pemanfaatan Teknologi Informasi Dalam Pembelajaran Jarak Jauh Di Tengah Pandemi Virus Corona Covid-19." JISAMAR (Journal of Information System, Applied, Management, Accounting and Researh) 4(2):30-36.

Pratiwi, Ika Ari, Sekar Dwi Ardianti, and Moh. Kanzunnudin. 2018. "Peningkatan Kemampuan Kerjasama Melalui Model Project Based Learning (PjBL) Berbantuan Metode Edutainment Pada Mata Pelajaran Ilmu Pengetahuan Sosial." Refleksi Edukatika : Jurnal Ilmiah Kependidikan $8(2): 177-82$.

Sadikin, Ali, and Afreni Hamidah. 2020. "Pembelajaran Daring Di Tengah Wabah Covid-19." Biodik 6(2):109-19.

Sari, Martala, Sri Utami Lestari, and Raudhah Awal. 2018. "Peningkatan Ketrampilan Mahasiswa Dalam Pengelolaan Sampah Organik Untuk Mewujudkan Green Campus Di Universitas Lancang Kuning." Dinamisia : Jurnal Pengabdian Kepada Masyarakat 2(2):193-96.

Wahyono, Poncojari, H. Husamah, and Anton Setia Budi. 2020. "Guru Profesional Di Masa Pandemi COVID-19: Review Implementasi, Tantangan, Dan Solusi Pembelajaran Daring." Jurnal Pendidikan Profesi Guru 1(1):51-65. 